\title{
Mechanistic Features of Isomerizing Alkoxycarbonylation of Methyl Oleate
}

\author{
Philipp Roesle, ${ }^{\dagger}$ Christoph J. Dürr, ${ }^{\dagger}$ Heiko M. Möller, ${ }^{* \dagger}$ Luigi Cavallo, ${ }^{\ddagger}$ Lucia Caporaso, ${ }^{* \perp}$ \\ and Stefan Mecking* ${ }^{\dagger}$ \\ ${ }^{\dagger}$ Chair of Chemical Materials Science, Department of Chemistry, University of Konstanz, 78464 Konstanz, Germany \\ ${ }^{\ddagger}$ Chemical and Life Sciences and Engineering, Kaust Catalysis Center, King Abdullah University of Science and Technology, Thuwal \\ 23955-6900, Saudi Arabia \\ ${ }^{\mathrm{I}}$ Department of Chemistry, University of Salerno, Via Ponte Don Melillo, 84084-Fisciano (SA), Italy
}

\begin{abstract}
The weakly coordinated triflate complex $\left[\left(\mathrm{P}^{\wedge} \mathrm{P}\right) \mathrm{Pd}(\mathrm{OTf})\right]^{+}(\mathrm{OTf})^{-}(1) \quad\left(\mathrm{P}^{\wedge} \mathrm{P}=1,3\right.$-bis (di-tert-butylphosphino)propane) is a suitable reactive precursor for mechanistic studies of the isomerizing alkoxcarbonylation of methyl oleate. Addition of $\mathrm{CH}_{3} \mathrm{OH}$ or $\mathrm{CD}_{3} \mathrm{OD}$ to 1 forms the hydride species $\left[\left(\mathrm{P}^{\wedge} \mathrm{P}\right) \mathrm{PdH}\left(\mathrm{CH}_{3} \mathrm{OH}\right)\right]^{+}(\mathrm{OTf})-\left(2-\mathrm{CH}_{3} \mathrm{OH}\right)$ or the deuteride $\left[\left(\mathrm{P}^{\wedge} \mathrm{P}\right) \mathrm{PdD}\left(\mathrm{CD}_{3} \mathrm{OD}\right)\right]^{+}(\mathrm{OTf})^{-}\left(2^{\mathrm{D}}\right.$. $\mathrm{CD}_{3} \mathrm{OD}$ ), respectively. Further reaction with pyridine cleanly affords the stable and isolable hydride $\left[\left(\mathrm{P}^{\wedge} \mathrm{P}\right) \mathrm{PdH}\right.$ (pyridine) $]^{+}\left(\mathrm{OTf}^{-}(2-\mathrm{pyr})\right.$. This complex yields the hydride fragment free of methanol by abstraction of pyridine with $\mathrm{BF}_{3} \cdot \mathrm{OEt}_{2}$ and thus provides an entry to mechanistic observations including intermediates reactive toward methanol. Exposure of methyl oleate (100 equiv) to $2^{\mathrm{D}}-\mathrm{CD}_{3} \mathrm{OD}$ resulted in rapid isomerization to the thermodynamic isomer distribution, $94.3 \%$ of internal olefins, $5.5 \%$ of $\alpha, \beta$-unsaturated ester and $<0.2 \%$ of terminal olefin. Reaction of 2-pyr/BF $3 . \mathrm{OEt}$, with a stoichiometric amount of $1^{1{ }^{13}} \mathrm{C}$-labeled 1-octene at $-800^{\circ} \mathrm{C}$ yields a $50: 50$ mixture of the linear alkyls $\left[\left(\mathrm{P}^{\wedge} \mathrm{P}\right) \mathrm{Pd}^{13} \mathrm{CH}_{2}\left(\mathrm{CH}_{2}\right)_{6} \mathrm{CH}_{3}\right]^{+}$and $\left[\left(\mathrm{P}^{\wedge} \mathrm{P}\right) \mathrm{PdCH}_{2}\left(\mathrm{CH}_{2}\right)_{6}{ }^{13} \mathrm{CH}_{3}\right]^{+}$(4a and $\left.4 \mathrm{~b}\right)$. Further reaction with ${ }^{13} \mathrm{CO}$ yields the linear acyls $\left.\left[\left(\mathrm{P}^{\wedge} \mathrm{P}\right) \mathrm{Pd}^{13} \mathrm{C}=\mathrm{O}\right)^{12 / 13} \mathrm{CH}_{2}\left(\mathrm{CH}_{2}\right)_{6}^{12 / 13} \mathrm{CH}_{3}(\mathrm{~L})\right]^{+}\left(5-\mathrm{L} ; \mathrm{L}=\right.$ solvent or $\left.{ }^{13} \mathrm{CO}\right)$. Reaction of 2-pyr/ $\mathrm{BF}_{3} \cdot \mathrm{OEt}_{2}$ with a stoichiometric amount of methyl oleate at $-80^{\circ} \mathrm{C}$ also resulted in fast isomerization to form a linear alkyl species $\left[\left(\mathrm{P}^{\wedge} \mathrm{P}\right) \mathrm{PdCH}_{2}\left(\mathrm{CH}_{2}\right)_{16} \mathrm{C}(=0) \mathrm{OCH}_{3}\right]^{+}(6)$ and a branched alkyl stabilized by coordination of the ester carbonyl group as a fout membered chelate $\left[\left(\mathrm{P}^{\wedge} \mathrm{P}\right) \mathrm{PdCH}\left\{\left(\mathrm{CH}_{2}\right)_{15} \mathrm{CH}_{3}\right\} \mathrm{C}(=\mathrm{O}) \mathrm{OCH}_{3}\right]^{+}(7)$. Addition of carbon monoxide $\left(2.5\right.$ equiv) at $-80^{\circ} \mathrm{C}$ restited in insertion to form the linear acyl carbonyl $\left[\left(\mathrm{P}^{\wedge} \mathrm{P}\right) \mathrm{PdC}(=\mathrm{O})\left(\mathrm{CH}_{2}\right)_{17} \mathrm{C}(=\mathrm{O}) \mathrm{OCH}_{3}(\mathrm{CO})\right]^{+}(8-\mathrm{CO})$ and the fivemembered chelate $\left[\left(\mathrm{P}^{\wedge} \mathrm{P}\right) \mathrm{PdC}(=\mathrm{O}) \mathrm{CH}\left\{\left(\mathrm{CH}_{2}\right)_{15} \mathrm{CH}_{3}\right\} \mathrm{C}(=\mathrm{O}) \mathrm{OCH}_{3}\right]^{+}(9)$. Exposure of 8-CO and 9 to ${ }^{13} \mathrm{CO}$ at $-50^{\circ} \mathrm{C}$ results in gradual incorporation of the ${ }^{13} \mathrm{C}$ label. Reversibility of $7+\mathrm{CO} \rightleftharpoons 9$ is also evidenced by $\Delta \mathrm{G}=-2.9 \mathrm{kcal} \mathrm{mol}^{-1}$ and $\Delta G^{\ddagger}=12.5 \mathrm{kal} \mathrm{mol}^{-1}$ from DFT studies. Addition of methanol at $-80^{\circ} \mathrm{C}$ results in methanolysis of $8-\mathrm{L}(\mathrm{L}=$ solvent $)$ to form the linear diester, 1,19-dimethylnonadecandioate, whereas 9 does not react and no branched diester is observed. DFT yields a barrier for methanolysis of $\Delta G^{\ddagger}=29.7 \mathrm{kcal} \mathrm{mol}^{-1}$ for the linear (8) vs $\Delta G^{\ddagger}=37.7 \mathrm{kcal} \mathrm{mol}^{-1}$ for the branched species (9).
\end{abstract}

\section{INTRODUCTION}

The utilization of renewable resources as a source of chemicals requires their efficient conversion to useful building blocks. Fatty acids are attractive feedstocks due to their unique, long methylene sequences. ${ }^{1}$ Their incorporation into linear, longchain $\alpha, \omega$-functionalized compounds is of interest, for example, for the generation of semicrystalline aliphatic polyesters and hydrophobic polyamides. The terminal functionalization of fatty acids is a synthetic challenge, however. Biotechnological ${ }^{2,3}$ as well as entirely chemical catalytic approaches are studied to this end. Among the latter, isomerizing hydroformylation by rhodium complexes is noteworthy in the context of the approach presented here. ${ }^{4}$

Alkoxycarbonylation is a well-known reaction that generates an ester function from an olefin, carbon monoxide, and an alcohol. ${ }^{5,6}$ Thus, methoxycarbonylation of ethylene to methyl propionate has recently been commercialized as part of a novel process for methyl methacrylate production. ${ }^{7}$ This reaction, which is also well understood mechanistically, ${ }^{6 \mathrm{~b}, c, 8}$ is catalyzed with high rates by palladium(II) complexes of 1,2$\left(\mathrm{CH}_{2} \mathrm{P}^{\mathrm{t}} \mathrm{Bu}_{2}\right)_{2} \mathrm{C}_{6} \mathrm{H}_{4}{ }^{6 \mathrm{a}}$ In order to fully incorporate the fatty acid chain in a linear fashion, a prior selective isomerization step is required, however. This is particularly difficult, as terminal olefins are thermodynamically strongly disfavored vs the internal double bonds of the substrate. Remarkably, palladium(II) catalysts modified with electron-rich, very bulky substituted diphosphine ligands (identical or similar to the ones 
reported for the aforementioned ethylene carbonylation $)^{9}$ nonetheless convert the double bond deep in the chain of an unsaturated fatty acid selectively to a terminal ester group (Scheme 1). ${ }^{10,11}$ Step-growth polymerization of the products,

Scheme 1. Isomerizing Alkoxycarbonylation of Methyl Oleate

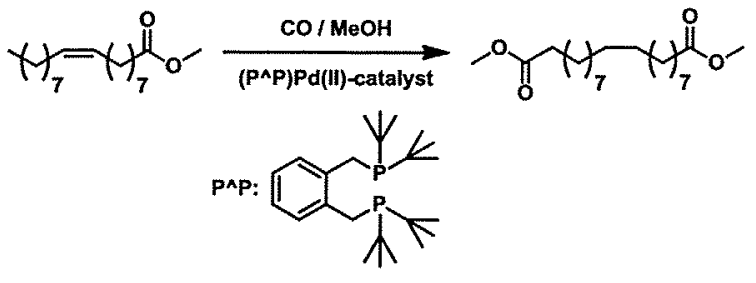

e.g. 1,19-dimethylnonadecandioate from methyl oleate, to novel, long-chain aliphatic polycondensates, and also their utility as precursors to novel $\alpha, \omega$-difunctional compounds like diols and diamines have been demonstrated. ${ }^{12}$

The origin of this unusual selectivity is unclear to date. We now present a full mechanistic analysis, based on observation and identification of intermediates by variable-temperature nuclear magnetic resonance (NMR) spectroscopy, complemented by theoretical studies of selected steps.

\section{RESULTS AND DISCUSSION}

For this study, the weakly coordinated Pd(II) triflate complex of the bulky-substituted electron-rich chelating diphosphine 1,3-bis (di-tert-butylphosphino)propane $\left[\left(\mathrm{P}^{\wedge} \mathrm{P}\right) \mathrm{Pd}\right.$ (OTf $)]^{+}(\mathrm{OTf})^{-}\left(1 ; \mathrm{P}^{\wedge} \mathrm{P}={ }^{\mathrm{t}} \mathrm{Bu} \mathrm{u}_{2} \mathrm{P}\left(\mathrm{CH}_{2}\right)_{3} \mathrm{P}^{\mathrm{t}} \mathrm{Bu}_{2}\right)$ proved to be a suitable precursor. From 1 , a clean hydride complex could be isolated that provides an entry into mechanistic studies (vide infra), which was not possible in our hands from the corresponding triflate complex of $1,2-\left(\mathrm{CH}_{2} \mathrm{P}^{t} \mathrm{Bu}_{2}\right)_{2} \mathrm{C}_{6} \mathrm{H}_{4}$ to date. 1 was accessed by reaction of the diphosphine with $\left[\mathrm{Pd}(\mathrm{dba})_{2}\right]$ and subsequent oxidation of the palladium metal with benzoquinone in the presence of trifluoromethanesulfonic acid (for synthetic procedures cf. the Supporting Information). ${ }^{6 \mathrm{~b}, 8 \mathrm{~b}}$ In an alkoxycarbonylation experiment at elevated temperature and CO pressure using 1 as a catalyst precursor, methyl oleate was converted to 1,19-dimethylnonadecandioate with high conversion and selectivity (cf. Supporting Information [SI]). This catalyst performance is similar to methoxycarbonylation of methyl oleate with the aforementioned diphosphine $1,2-\left(\mathrm{CH}_{2} \mathrm{P}^{\mathrm{t}} \mathrm{Bu}_{2}\right)_{2} \mathrm{C}_{6} \mathrm{H}_{4}{ }^{12}$ in detail the reaction rate and selectivity are slightly lower with 1 by comparison to $\left[\left\{1,2-\left(\mathrm{CH}_{2} \mathrm{P}^{\mathrm{t}} \mathrm{Bu}_{2}\right)_{2} \mathrm{C}_{6} \mathrm{H}_{4}\right\} \mathrm{Pd}(\mathrm{OTf})\right]^{+}(\mathrm{OTf})^{-}$. Computational studies were carried out on $1,2-\left(\mathrm{CH}_{2} \mathrm{P}^{\mathrm{t}} \mathrm{Bu}_{2}\right)_{2} \mathrm{C}_{6} \mathrm{H}_{4}$-coordinated species, as the rigid phosphine backbone reduces the number of conformers and facilitates the identification of ground and transition states.

Pd(II)-Hydride Species. To provide an entry into the studies of the various reaction steps and intermediates, palladium hydrides $\left[\left(\mathrm{P}^{\wedge} \mathrm{P}\right) \mathrm{PdH}(\mathrm{L})\right]^{+}\left(\mathrm{P}^{\wedge} \mathrm{P}={ }^{\mathrm{t}} \mathrm{B} \mathrm{u}_{2} \mathrm{P}\right.$. $\left.\left(\mathrm{CH}_{2}\right)_{3} \mathrm{P}^{\mathrm{t}} \mathrm{Bu}_{2}\right)$ were found to be suitable reactive species. Dissolution of the triflate complex $\left[\left(\mathrm{P}^{\wedge} \mathrm{P}\right) \mathrm{Pd}(\mathrm{OTf})\right]^{+}(\mathrm{OTf})^{-}$ (1) in $\mathrm{CD}_{2} \mathrm{Cl}_{2}$ containing $\mathrm{CH}_{3} \mathrm{OH}$ or $\mathrm{CD}_{3} \mathrm{OD}$, respectively, at room temperature resulted in clean conversion to the solvent coordinated hydride $\left[\left(\mathrm{P}^{\wedge} \mathrm{P}\right) \mathrm{PdH}\left(\mathrm{CH}_{3} \mathrm{OH}\right)\right]^{+}(\mathrm{OTf})^{-}(2-$ $\mathrm{CH}_{3} \mathrm{OH}$ ) or corresponding deuteride $2^{\mathrm{D}}-\mathrm{CD}_{3} \mathrm{OD}$ (Figure $\mathrm{S} 15, \mathrm{SI})$. Key resonances $\left(-80^{\circ} \mathrm{C}\right)$ of $2-\mathrm{CH}_{3} \mathrm{OH}$ are observed at $\delta^{1} \mathrm{H}-9.52$ (doublet of doublet with ${ }^{2} J_{\mathrm{PH}_{\text {wax }}}=195.7 \mathrm{~Hz}$ and ${ }^{2} J_{\mathrm{PH}_{i s}}=18.9 \mathrm{~Hz}$ ) for $\mathrm{Pd}-\mathrm{H}$ and $\delta^{31} \mathrm{P} 73.19$ and 20.79 (doublet each, ${ }^{2} J_{\mathrm{pp}}=23.2 \mathrm{~Hz}$ ) for the inequivalent phosphorus atoms (for full characterization of all compounds cf. the SI).

Addition of carbon monoxide to $2-\mathrm{CH}_{3} \mathrm{OH}$ or $2^{\mathrm{D}}-\mathrm{CD}_{3} \mathrm{OD}$ at $-78{ }^{\circ} \mathrm{C}$ resulted in displacement of coordinated methanol by the strongly coordinating $\mathrm{CO}$ ligand to form $\left[\left(\mathrm{P}^{\wedge} \mathrm{P}\right) \mathrm{PdH} /\right.$ $\mathrm{D}(\mathrm{CO})]^{+}(\mathrm{OTf})^{-}\left(2-\mathrm{CO} / 2^{\mathrm{D}}-\mathrm{CO}\right)$, or $2-{ }^{13} \mathrm{CO}$ if ${ }^{13} \mathrm{CO}$ was used. Key resonances $\left(-80^{\circ} \mathrm{C}\right)$ of $2-\mathrm{CO}$ are observed at $\delta^{1} \mathrm{H}$ -5.51 (doublet of doublet with ${ }^{2} J_{\mathrm{PH}_{\text {trans }}}=169.5 \mathrm{~Hz}$ and ${ }^{2} \mathrm{JPH}_{\text {os }}=$ $20.8 \mathrm{~Hz}$ ) for $\mathrm{Pd}-\mathrm{H}$ and $\delta^{31} \mathrm{P} 59.60$ and 31.12 (doublet each, ${ }^{2} J_{\mathrm{pp}}=27.6 \mathrm{~Hz}$ ) for the inequivalent phosphorus atoms. In ${ }_{2-}{ }^{13} \mathrm{CO}$ additional ${ }^{2} J_{\mathrm{PC}}$ couplings $\left({ }^{2} J_{\mathrm{PC}_{\text {tars }}}=100.5 \mathrm{~Hz}\right.$ and ${ }^{2} J_{\mathrm{PC}} \mathrm{C}_{i \mathrm{c}}$ $=12.1 \mathrm{~Hz}$ ) are observed. The resonance of coordinated ${ }^{13} \mathrm{CO}$ is observed at $\delta{ }^{13} \mathrm{C} 183.47$ (doublet of doublet), which is very similar to free ${ }^{13} \mathrm{CO}\left(\delta{ }^{13} \mathrm{C} 184.13\right)$. Nonetheless, coordination of $\mathrm{CO}$ is evidenced by the observed ${ }^{2} \mathrm{JC}_{\mathrm{pC}}$ couplings in ${ }^{13} \mathrm{C}$ NMR spectra. Note that upon heating of $2{ }^{13} \mathrm{CO}$ to room temperature quantitative formation of $\left[\left(\mathrm{P}^{\wedge} \mathrm{P}\right) \mathrm{Pd}(\mu-\mathrm{H})\right.$ $\left.\left(\mu{ }^{13} \mathrm{CO}\right) \mathrm{Pd}\left(\mathrm{P}^{\wedge} \mathrm{P}\right)\right]^{+}(\mathrm{OTf})^{-}\left(3 ; \delta{ }^{1} \mathrm{H}-7.79\right.$ (quintet) ${ }^{2} J_{\mathrm{PH}}=$ $42.8 \mathrm{~Hz}$ for $\mu-\mathrm{H}, \delta^{31} \mathrm{p} 38.64$ (doublet) ${ }^{2} J_{\mathrm{PC}}=30.6 \mathrm{~Hz}$ and $\delta$ ${ }^{13} \mathrm{C} 230.00$ for $\mu-{ }^{13} \mathrm{CO}$ (quintet) ${ }^{2} \mathrm{JPC}_{\mathrm{PC}}=30.6 \mathrm{~Hz}$ ) was observed within minutes. A characteristic of this palladium(I) complex is a rapid fluxional process, that results in rapid site exchange of al ${ }^{31} \mathrm{P}$ nuclei leading to a single resonance in ${ }^{31} \mathrm{P}$ NMR spectroscopy, even at temperatures as low as $-80{ }^{\circ} \mathrm{C}$. This characteristic has been observed previously for binuclear palladium(I) species with $\mu$-H and $\mu$-CO bridging ligands with different diphosphines. ${ }^{8 \mathrm{~d}, 13}$ Also, a mechanism for the reductive formation of a species similar to 3 was suggested. ${ }^{14}$

For the anticipated observation of $\mathrm{CO}$ insertion reactions into palladium alkyl species the absence of alcohol is crucial, as immediate methanolysis occurs otherwise (vide infra). Addition of pyridine to $2-\mathrm{CH}_{3} \mathrm{OH}$ resulted in displacement of methanol from the solvent coordinated hydride, to yield $\left[\left(\mathrm{P}^{\wedge} \mathrm{P}\right) \mathrm{PdH}-\right.$ (pyridine) $]^{+}(\mathrm{OTf})^{-}$(2-pyr) with $\delta{ }^{1} \mathrm{H}-9.07$ (doublet of doublet with ${ }^{2} J_{\mathrm{PH}_{\text {trans }}}=190.6 \mathrm{~Hz}$ and ${ }^{2} J_{\mathrm{PH}}=17.7 \mathrm{~Hz}$ ) for $\mathrm{Pd}-\mathrm{H}$ and $\delta^{31} \mathrm{p} 65.32$ and 19.68 (doublet each, ${ }^{2} J_{\mathrm{pp}}=26.0 \mathrm{~Hz}$ ) for the inequivalent phosphorus atoms $\left(-80^{\circ} \mathrm{C}\right.$; Figure 1$)$. This pyridine adduct was isolated by removing the solvent in vacuum as a stable off-white solid (SI).

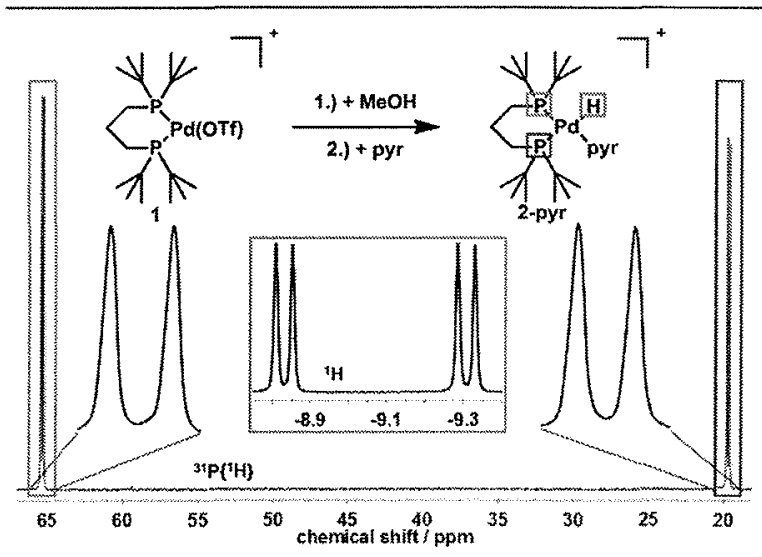

Figure 1. ${ }^{31} \mathrm{P}\left\{{ }^{1} \mathrm{H}\right\}$ NMR spectrum $\left(-80{ }^{\circ} \mathrm{C}\right)$ of $\left[\left(\mathrm{P}^{\wedge} \mathrm{P}\right) \mathrm{PdH}-\right.$ (pyridine) $]^{+}(\mathrm{OTf})^{-}(2-\mathrm{pyr})$ in $\mathrm{CD}_{2} \mathrm{Cl}_{2}$. Insert: $\mathrm{Pd}-\mathrm{H}$ resonance. 
Isomerization with Pd(II)-Hydrides. Exposure of excess methyl oleate (100 equiv) to a catalytic amount of $2^{\mathrm{D}}-\mathrm{CD}_{3} \mathrm{OD}$ in a $\mathrm{CD}_{3} \mathrm{OD} / \mathrm{CD}_{2} \mathrm{Cl}_{2}$ mixture $(2 / 3$ by volume) in an NMR tube at room temperature resulted in immediate isomerization of the double bond to an equilibrium of all isomers (94.3\% of internal olefins, $5.5 \%$ of $\alpha, \beta$-unsaturated ester, and $<0.2 \%$ of terminal olefin (Figures S13 and S14 and Table S3, SI). This observed distribution is confirmed to correspond to the thermodynamic distribution by isomerization experiments on other olefins, for which thermodynamic data is available (Tables $\mathrm{S} 1$ and $\mathrm{S} 2, \mathrm{SI}) .^{15}$ Isomerization of methyl 5 -hexenoate and 1-octene, respectively, by $2^{\mathrm{D}}-\mathrm{CD}_{3} \mathrm{OD}$ in $\mathrm{CD}_{3} \mathrm{OD}$ yielded the thermodyamic distribution within experimental error, and correcting for chain lengths the portion of 1 -olefin and $\alpha, \beta$ unsaturated ester agree with the isomer composition obtained from methyl oleate.

Isomerization was also observed in the presence of carbon monoxide. Ten equivalents of carbon monoxide were added at room temperature to a solution of 2-pyr in $\mathrm{C}_{2} \mathrm{D}_{2} \mathrm{Cl}_{4}$, which resulted in displacement of pyridine by $\mathrm{CO}$ and formation of complex 3. Upon addition of 10 equiv of methyl oleate to this solution isomerization was observed via ${ }^{1} \mathrm{H}$ NMR spectroscopy. At $50{ }^{\circ} \mathrm{C}$ resonances of the $\alpha, \beta$-unsaturated ester as well as of the internal olefins appeared. Heating the sample to $70^{\circ} \mathrm{C}$ led to faster isomerization but also fast decomposition (within 30 min) of 3 forming palladium black and free protonated ligand (evidenced by its signals in ${ }^{1} \mathrm{H}$ and ${ }^{31} \mathrm{P}$ NMR spectroscopy). While this experiment does not distinguish between the effect of reversible coordination of $\mathrm{CO}$ and of formation of 3 , which occurs here, on the rate of isomerization, it is evident that the presence of $\mathrm{CO}$ as a relatively strongly binding donor does not prevent isomerization.

Insertion of 1-Octene and $\mathrm{CO}$ into $\mathrm{Pd}(\mathrm{II})$-Hydrides. The capability of the hydride species 2 for very rapid isomerization was illuminated further by stoichiometric experiments at low temperature. Abstraction of pyridine from 2-pyr with a stoichiometric amount of $\mathrm{BF}_{3} \cdot \mathrm{OEt}_{2}$ at $0{ }^{\circ} \mathrm{C}$ in $\mathrm{CD}_{2} \mathrm{Cl}_{2}$ yielded a reactive species, ${ }^{16}$ which upon addition of $1 .{ }^{13} \mathrm{C}$ labeled 1 -octene ( 0.95 equiv) at $-80^{\circ} \mathrm{C}$ immediately inserted the olefin cleanly and completely to form complex 4 (Scheme 2

Scheme 2. Stoichiometric Insertion of $1-{ }^{13} \mathrm{C}$-Labeled 1Octene into Palladium Hydride Species

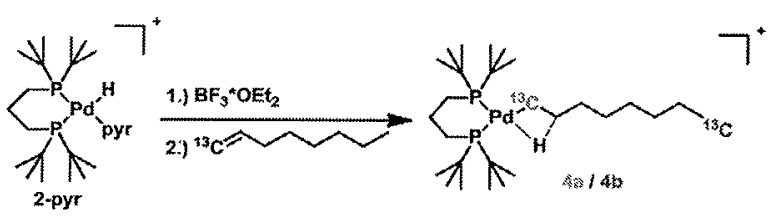

and Figures S16 and S17, SI). Remarkably, only this linear primary alkyl is observed. Moreover, the ${ }^{13} \mathrm{C}$ label is not only found in the $\alpha$-position $\left[\left(\mathrm{P}^{\wedge} \mathrm{P}\right) \mathrm{Pd}^{13} \mathrm{CH}_{2}\left(\mathrm{CH}_{2}\right)_{6} \mathrm{CH}_{3}\right]^{+}(4 \mathrm{a})$, but in an equal amount (50:50) also in the terminal position, $\left[\left(\mathrm{P}^{\wedge} \mathrm{P}\right) \mathrm{Pd}\left(\mathrm{CH}_{2}\right)_{7}{ }^{13} \mathrm{CH}_{3}\right]^{+}(4 \mathrm{~b})$. Key resonances of $4 \mathrm{a}$ and $4 \mathrm{~b}$ are $\delta{ }^{13} \mathrm{C} 35.08\left(\mathrm{PdCH}_{2}\right)$ with ${ }^{2} J_{\mathrm{PC}_{\text {trans }}}=39.0 \mathrm{~Hz}\left({ }^{2} \mathrm{PC}_{\text {pis }}\right.$ is not resolved) and $14.11\left(\mathrm{CH}_{2} \mathrm{CH}_{3}\right)$, and $\delta{ }^{31} \mathrm{p} 61.73$ (doublet with ${ }^{2} J_{\mathrm{Pp}}=35.7 \mathrm{~Hz}$ ) and 38.60 (doublet with ${ }^{2} J_{\mathrm{pp}}=35.7 \mathrm{~Hz}$, and a further doublet splitting in $4 \mathrm{a}$ by $\left.{ }^{2} J_{\mathrm{PC}_{\text {tras }}}=39.0 \mathrm{~Hz}\right) .{ }^{17}$ Furthermore, insertion of 2-octene into 2-pyr $/ \mathrm{BF}_{3} \cdot \mathrm{OEt}_{2}$ leads to identical resonances in the ${ }^{31} \mathrm{P}$ NMR spectrum. This shows that even at this low temperature the metal center is running along the alkyl chain by a series of rapid insertion and $\beta$-hydride elimination events. The chemical shifts of the phosphorus atoms observed here are not altered significantly by the presence of methanol. ${ }^{18}$ This suggests that the fourth coordination site is likely occupied by a $\beta$-agostic interaction rather than coordination of methanol solvent.

Addition of 1.5 equiv of ${ }^{13} \mathrm{CO}$ to complex 4 at $-78{ }^{\circ} \mathrm{C}$ resulted in insertion of ${ }^{13} \mathrm{CO}$ to form the linear acyl complex $\left[\left(\mathrm{P}^{\wedge} \mathrm{P}\right) \mathrm{Pd}^{13} \mathrm{C}(=\mathrm{O})^{12 / 13} \mathrm{CH}_{2}\left(\mathrm{CH}_{2}\right)_{6}{ }^{12 / 13} \mathrm{CH}_{3}(\mathrm{~L})\right]^{+}(5-\mathrm{L}, \mathrm{L}=$ solvent, $\delta^{31} \mathrm{P} 76.42$ and 34.78$)$ and the acyl carbonyl complex $5-{ }^{13} \mathrm{CO}$ (with $\delta^{31} \mathrm{P} 31.49$ and 28.12 ). In these products of $\mathrm{CO}$ insertion the ${ }^{13} \mathrm{C}$-label from the olefin is also evenly distributed in the $\alpha$ - and the terminal position of the acyl fragment, as evidenced clearly by the coupling patterns in the ${ }^{13} \mathrm{C}$ and ${ }^{31} \mathrm{P}$ NMR spectra (Figures S18 and S19, SI). ${ }^{19}$ Note that due to the use of substoichiometric amounts of olefin in generation of complex 4 (vide supra), addition of ${ }^{13} \mathrm{CO}$ to $4 \mathrm{a}$ and $4 \mathrm{~b}$, also generated the hydrido carbonyl complex $2-{ }^{13} \mathrm{CO}$ (Figure S20, $\mathrm{SI})$. These experiments show that insertion of $\mathrm{CO}$ is only observed into the linear alkyl species. This is notable because, though only the primary alkyls are observed as products of insertion of internal olefin into $\mathrm{Pd}-\mathrm{H}$ (vide supra), secondary alkyls must occur in small concentrations as intermediates of isomerization.

Insertion of methyl oleate and $\mathrm{CO}$ into $\mathrm{Pd}(\mathrm{II})$ Hydrides. Reaction of $2-\mathrm{pyr} / \mathrm{BF}_{3} \cdot \mathrm{OEt}_{2}$ at $-80{ }^{\circ} \mathrm{C}$ with 0.95 equiv of methyl oleate ${ }^{13} \mathrm{C}$-labeled at the carbonyl group afforded two novel species, 6 and 7 (Scheme 3 and Figure S22 $\mathrm{SI}$ ), in a ratio of 1 to 4 (calculated from integration of ${ }^{31} \mathrm{P}$ NMR spectra).

Scheme 3. Stoichiometric Insertion of Methyl Oleate into Palladium Hydride Species
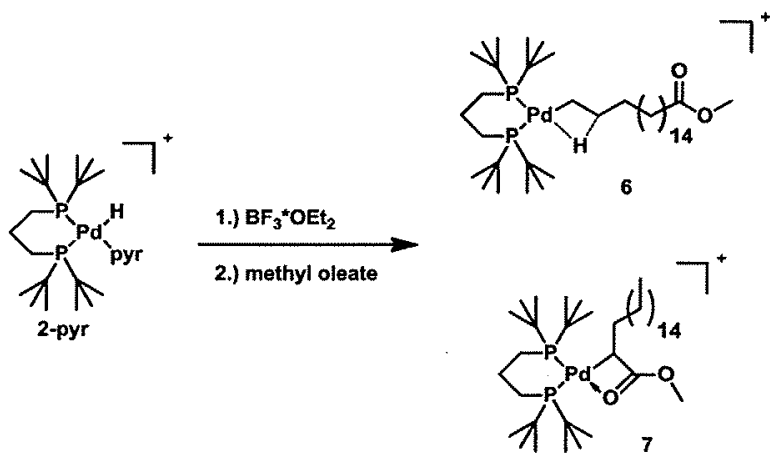

On the basis of its ${ }^{31} \mathrm{P}$ resonances $\left(\delta{ }^{31} \mathrm{P} 61.80\right.$ and 38.70 ; doublet each with ${ }^{2} J_{p p}=35.8 \mathrm{~Hz}$ ) being virtually identical to the aforementioned linear insertion product of 1 -octene (4 Table 1), a carbonyl resonance $\left({ }^{13} \mathrm{C} 174.93\right)$ identical to free methyl oleate and otherwise conclusive spectral data, 6 was identified as the linear alkyl $\left[\left(\mathrm{P}^{\wedge} \mathrm{P}\right) \mathrm{PdCH}_{2}\right.$. $\left.\left(\mathrm{CH}_{2}\right)_{16}{ }^{13} \mathrm{COOCH}_{3}\right]^{+}$(Figure S23, SI). $7\left({ }^{13} \mathrm{C}\left({ }^{13} \mathrm{C}=\mathrm{O}\right)\right.$ 168.10 and $\delta^{31} \mathrm{P} 65.73$ (doublet of doublet with ${ }^{2} J_{\mathrm{pp}}=41.0 \mathrm{~Hz}$ and ${ }^{3} J_{\mathrm{PC}}=3.5 \mathrm{~Hz}$ ) and 37.76 (doublet with ${ }^{2} J_{\mathrm{pp}}=41.0 \mathrm{~Hz}$ ) was identified as the branched alkyl $\left[\left(\mathrm{P}^{\wedge} \mathrm{P}\right) \mathrm{PdCH}\right.$ $\left.\left\{\left(\mathrm{CH}_{2}\right)_{15} \mathrm{CH}_{3}\right\}^{13} \mathrm{COOCH}_{3}\right]^{+}$with the metal-bound carbon directly adjacent to the ester function (Figure S24, SI). Evidence for this structure arises from the observed coupling of one ${ }^{31} \mathrm{P}$ resonance to the ${ }^{13} \mathrm{C}$ label, and particularly from ${ }^{1} \mathrm{H},{ }^{13} \mathrm{C}$ HSQC and ${ }^{1} \mathrm{H}_{,}^{13} \mathrm{C}$ HMBC correlation experiments in 
Table $1 .{ }^{31} \mathrm{P}\left\{{ }^{1} \mathrm{H}\right\}$ NMR chemical shifts and coupling constants of relevant intermediates. ${ }^{a}$

$\begin{array}{lcccc}\text { compound } & \delta P_{2} & 8 \mathrm{P}_{\mathrm{B}} & \mathrm{J}_{\mathrm{pP}} / \mathrm{Hz} \\ 1^{b} & & 79.39 & & - \\ 2-\mathrm{CH}_{3} \mathrm{OH}^{c} & 73.19 & 20.79 & 23.2 \\ 2-\mathrm{CO} & 59.60 & 31.13 & 27.6 \\ 2-\mathrm{pyr} & 65.32 & 19.68 & 26.0 \\ 4 & 61.73 & 38.60 & 39.0 \\ 6 & 61.80 & 38.70 & 35.8 \\ 5 & 76.42 & 34.78 & 43.7 \\ 8 & 76.52 & 34.86 & 44.5 \\ 5-{ }^{13} \mathrm{CO} & 31.49 & 28.12 & 60.0 \\ 8-{ }^{13} \mathrm{CO} & 31.50 & 28.20 & 60.5 \\ 7 & 65.73 & 37.76 & 41.0 \\ 9 & 58.31 & 24.06 & 49.6\end{array}$

${ }^{a} \mathrm{CD}_{2} \mathrm{Cl}_{2},-80{ }^{\circ} \mathrm{C}$, unless noted otherwise; ${ }^{b} \mathrm{CD}_{2} \mathrm{Cl}_{2}, 25{ }^{\circ} \mathrm{C} ;{ }^{c} \mathrm{CD}_{2} \mathrm{Cl}_{2} /$ $\mathrm{CH}_{3} \mathrm{OH}(\mathrm{v} / \mathrm{v}=3 / 2),-80^{\circ} \mathrm{C}$.

which the methine group next to the palladium center was clearly identified to be in the $\alpha$ position of the carbonyl group (Figures S25-S27, SI). That this four-membered chelate prevails in stability over the five- and six-membered isomers is likely a result of the very bulky tert-butyl substituted diphosphine ligand, which restricts the available space at the metal center.

This finding is also supported by theoretical studies, which find a four-membered chelate to be lower in energy than the five-membered analogue (by $2.6 \mathrm{kcal} \mathrm{mol}^{-1}$, cf. SI, Figure S43). By comparison, for analogous complexes in which the bulky tert-butyl substituents of the diphosphine are replaced by methyl groups the five-membered chelate was found to be energetically favorable indeed (by $3.3 \mathrm{kcal} \mathrm{mol}^{-1}$ ).

Upon addition of ${ }^{13} \mathrm{CO}$ (1.5 equiv) species 6 and 7 react to form the novel compounds $8-\mathrm{L}\left(\mathrm{L}=\right.$ solvent), $8-{ }^{13} \mathrm{CO}$ and 9 (Scheme 4).

Scheme 4. Stoichiometric Insertion of Carbon Monoxide into Methyl Oleate Insertion Products

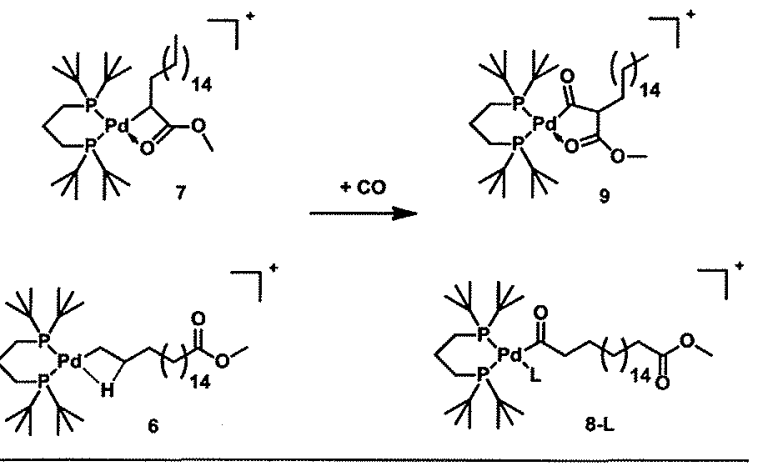

8-L was identified as the linear acyl species $\left[\left(\mathrm{P}^{\wedge} \mathrm{P}\right) \mathrm{Pd}^{13} \mathrm{C}(=\right.$ O) $\left.\left(\mathrm{CH}_{2}\right)_{17}{ }^{13} \mathrm{COOCH}_{3}(\mathrm{~L})\right]^{+}$with $\delta{ }^{31} \mathrm{P} 76.52$ and 34.86 (Figure $\mathrm{S} 28, \mathrm{SI}){ }^{20} 8{ }^{13} \mathrm{CO}$ is the linear acyl carbonyl species $\left[\left(\mathrm{P}^{\wedge} \mathrm{P}\right) \mathrm{Pd}^{13} \mathrm{C}(=\mathrm{O})\left(\mathrm{CH}_{2}\right){ }_{17}^{13} \mathrm{COOCH}_{3}\left({ }^{13} \mathrm{CO}\right)\right]^{+}$with $\delta{ }^{31} \mathrm{P}$ 31.50 and 28.20 and an additional resonance for coordinated ${ }^{13} \mathrm{CO}$ in the carbon NMR spectrum (Figure $\left.\mathrm{S} 29, \mathrm{SI}\right) .{ }^{21} \mathrm{The}^{31} \mathrm{P}$ resonances of $8-\mathrm{L}$ and $8{ }^{13} \mathrm{CO}$ are in good agreement to those of 5-L and $5{ }^{13} \mathrm{CO}$, respectively (Table $\mathrm{I}$ ). 9 was identified as the five-membered chelate $\left[\left(\mathrm{P}^{\wedge} \mathrm{P}\right) \mathrm{Pd}^{13} \mathrm{C}(=\mathrm{O}) \mathrm{CH}\right.$ $\left.\left\{\left(\mathrm{CH}_{2}\right)_{15} \mathrm{CH}_{3}\right\}^{13} \mathrm{COOCH}_{3}\right]^{+}$with $\delta{ }^{31} \mathrm{P} 58.31$ and 24.06
(Figure S30, SI)..$^{22}$ The ratio of linear $\left(8-\mathrm{L}\right.$ and $8-{ }^{13} \mathrm{CO}$ ) versus branched (9) carbonyl species is $\sim 1: 1$ (determined by integration of the ${ }^{31} \mathrm{P}$ NMR spectra). Notably, even in the presence of an excess of the strongly coordinating ligand ${ }^{13} \mathrm{CO}$ ( $>6$ equiv) the chelate 9 is not opened, and formation of 9. ${ }^{13} \mathrm{CO}$ is not observed.

Reversibility of CO Insertion. In the overall mechanistic picture, the reversibility of carbon monoxide insertion in the branched product pathway turns out to be a crucial issue (vide infra). To this end, ${ }^{13} \mathrm{C}$-labeled carbon monoxide was added to a sample of $8-\mathrm{CO}$ and 9 at $-50^{\circ} \mathrm{C}$. This sample had been prepared as described above but without using ${ }^{13} \mathrm{C}$-labeled compounds and employing 2.5 equiv of $\mathrm{CO}$ to ensure that complexes 6 and 7 are converted completely to 8-CO and 9 (Figure S36-S38, SI). After addition of 10 equiv of ${ }^{13} \mathrm{CO}$ at $-78{ }^{\circ} \mathrm{C}$ the sample was warmed to $-50{ }^{\circ} \mathrm{C}$ and the exchange reaction was monitored via ${ }^{31} \mathrm{P}$ NMR spectroscopy. Exchange is evidenced by gradual appearance of additional ${ }^{2} J_{\mathrm{PC}}$ couplings (Figures 2 and S39 and S40, SI), which was completed within 5 h.

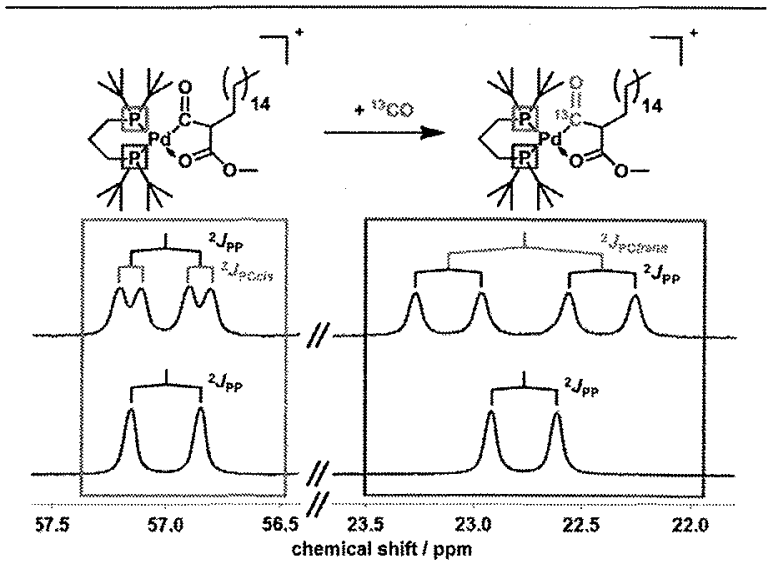

Figure 2. Detail of ${ }^{31} \mathrm{P}\left\{{ }^{1} \mathrm{H}\right\}$ NMR spectra (measured at $-80^{\circ} \mathrm{C}$ ) of $\mathrm{CO}$ exchange in complex 9 (bottom: spectrum before addition of

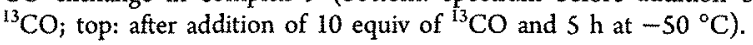

The reversible nature of this $\mathrm{CO}$ insertion is further corroborated by DFT studies (Figures $\mathrm{S} 44$ and $\mathrm{S} 45, \mathrm{SI}$ ). The reaction $7+\mathrm{CO} \rightleftarrows 9$ is nearly thermoneutral $(\Delta G=-2.9 \mathrm{kcal}$ $\left.\mathrm{mol}^{-1}\right)$, and the insertion barrier of $\Delta G^{\ddagger}=12.5 \mathrm{kcal} \mathrm{mol}^{-1}$ is relatively low (Figure 3). Note that this differs from the nature of the $\mathrm{CO}$ insertion into the linear alkyl $(6+\mathrm{CO} \rightleftarrows 8)$ which is associated with a slightly lower barrier $\left(\Delta G^{\ddagger}=9.2 \mathrm{kcal} \mathrm{mol}^{-1}\right)$ but higher energy gain of $\Delta G=-9.3 \mathrm{kcal} \mathrm{mol}^{-1}$ (Figure 4). Nevertheless, CO exchange was observed by NMR spectroscopy for both reactions.

Methanolysis. The final step of the catalytic cycle is alcoholysis of the acyl species. Addition of 0.5 equiv of methanol to a mixture of the acyl species 8-L, $8{ }^{13} \mathrm{CO}$ and 9 (prepared by addition of 1.5 equiv of ${ }^{13} \mathrm{CO}$ to 6 and 7) at -80 ${ }^{\circ} \mathrm{C}$ resulted in disappearance of the ${ }^{31} \mathrm{P}$ NMR signals of $8-\mathrm{L}$ and immediate formation of the linear 1,19-dimethylnonadecandioate. No formation of the branched diester was observed, as evidenced by comparison with the ${ }^{13} \mathrm{C}$ NMR shifts of a genuine sample of the malonic ester MeOOC-CHR-COOMe $(\mathrm{R}=$ $\mathrm{C}_{16} \mathrm{H}_{33}$ ) prepared independently. ${ }^{23}$ With excess $\mathrm{CO}$, methanolysis appears to be slower. Addition of 20 equiv of methanol to $8{ }^{13} \mathrm{CO}$ and 9 (prepared by addition of 10 equiv of ${ }^{13} \mathrm{CO}$ to 


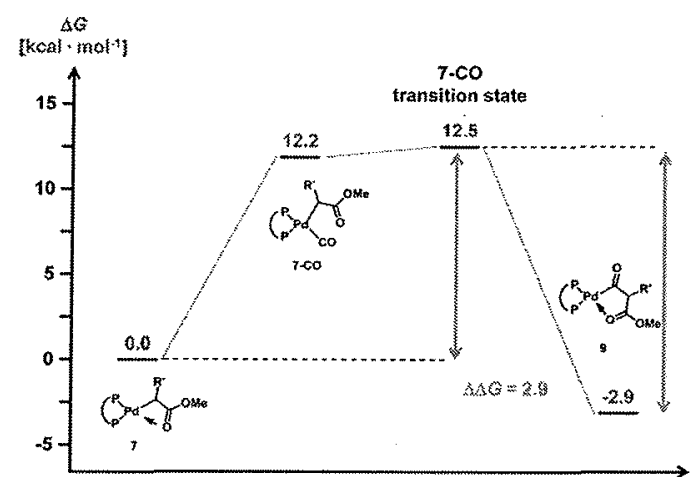

Figure 3. Energy profile of the $\mathrm{CO}$ insertion into the branched metal alkyl 7.

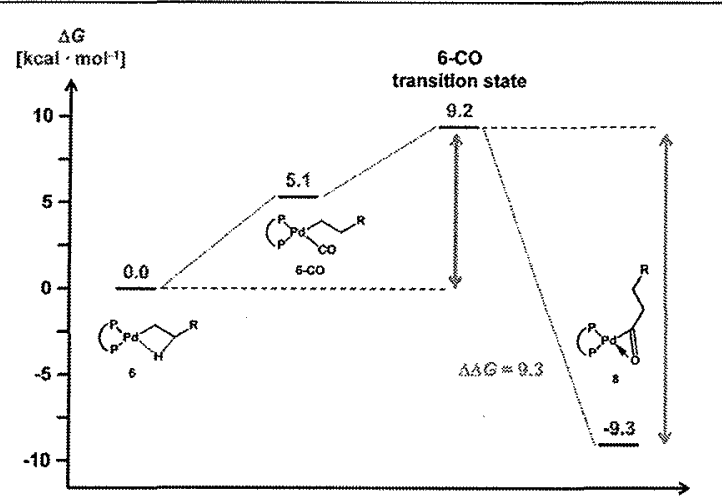

Figure 4. Energy profile of the $\mathrm{CO}$ insertion into the linear metal alkyl 6.

6 and 7) at $-80{ }^{\circ} \mathrm{C}$ did not result in any observable methanolysis (evidenced by ${ }^{31} \mathrm{P}$ and ${ }^{13} \mathrm{C}$ NMR spectroscopy). Upon warming this sample to room temperature, formation of the linear 1,19-dimethylnonadecandioate and the bridged hydride carbonyl complex 3 was observed. A trace amount $(<1 \%)$ of the branched ester was found, as evidenced by its ${ }^{13} \mathrm{C}$ NMR shifts (Figures S33-S35, SI). Also, under reaction conditions of preparative methyl oleate methoxcarbonylation (methyl oleate $/ \mathrm{Pd}=125 / 1 ; 20$ bar $\mathrm{CO} ; 90{ }^{\circ} \mathrm{C} ; 90 \mathrm{~h}$ ) the formation of a small amount $(<0.5 \%)$ of the branched diester was observed, as evidenced by gas chromatography (GC), by comparison to a genuine sample of the compound.

To further work out the reactivity differences responsible for the overall selectivity, the reaction was studied at $-60{ }^{\circ} \mathrm{C}$ starting directly from a methanol solution $\left(\mathrm{CD}_{3} \mathrm{OD} / \mathrm{CD}_{2} \mathrm{Cl}_{2}=\right.$ $2 / 3$ by volume). Dissolving complex 1 in this solvent mixture yielded $2^{\mathrm{D}}-\mathrm{CD}_{3} \mathrm{OD}$ (vide supra). Addition of 2 equiv of methyl oleate afforded a mixture of the alkyls 6 and $7 .{ }^{24}$ Upon addition of 5 equiv of ${ }^{13} \mathrm{CO}$ to this solution, complex 9 formed (as evidenced by ${ }^{13} \mathrm{C}$ and ${ }^{31} \mathrm{P}$ NMR spectroscopy) along with some linear diester, 1,19-dimethylnonadecandioate (Figures S41 and $\mathrm{S} 42, \mathrm{SI}$ ). Notably, 8-L or $8{ }^{13} \mathrm{CO}$ are not observed under these conditions, due to rapid methanolysis to the linear diester. Finally, warming this sample to room temperature again results in the formation of further linear 1,19-dimethylnonadecandioate, trace amounts $(<1 \%)$ of the branched diester, and complex $3 .^{2 S}$

These observation indicate that methanolysis of the linear acyl complexes (8-L and 8-CO) is faster than methanolysis of the branched acyl species 9 . This decisive difference in the methanolysis rate was further confirmed by DFT studies. For methanolysis of the linear acyl species (8), a barrier of $\Delta G^{\ddagger}=$ $29.7 \mathrm{kcal} \mathrm{mol}^{-1}$ was calculated by comparison to $\Delta G^{\ddagger}=37.7$ $\mathrm{kcal} \mathrm{mol}^{-1}$ for methanolysis of the branched species (9) (cf. SI for details, Figures S46 and S47).

\section{SUMMARY AND CONCLUSIONS}

Our comprehensive direct experimental observations of intermediates and their reactivity at low temperatures reveal the following key mechanistic features (Figure 5). In the isomerization equilibrium along the alkyl chain, the terminal

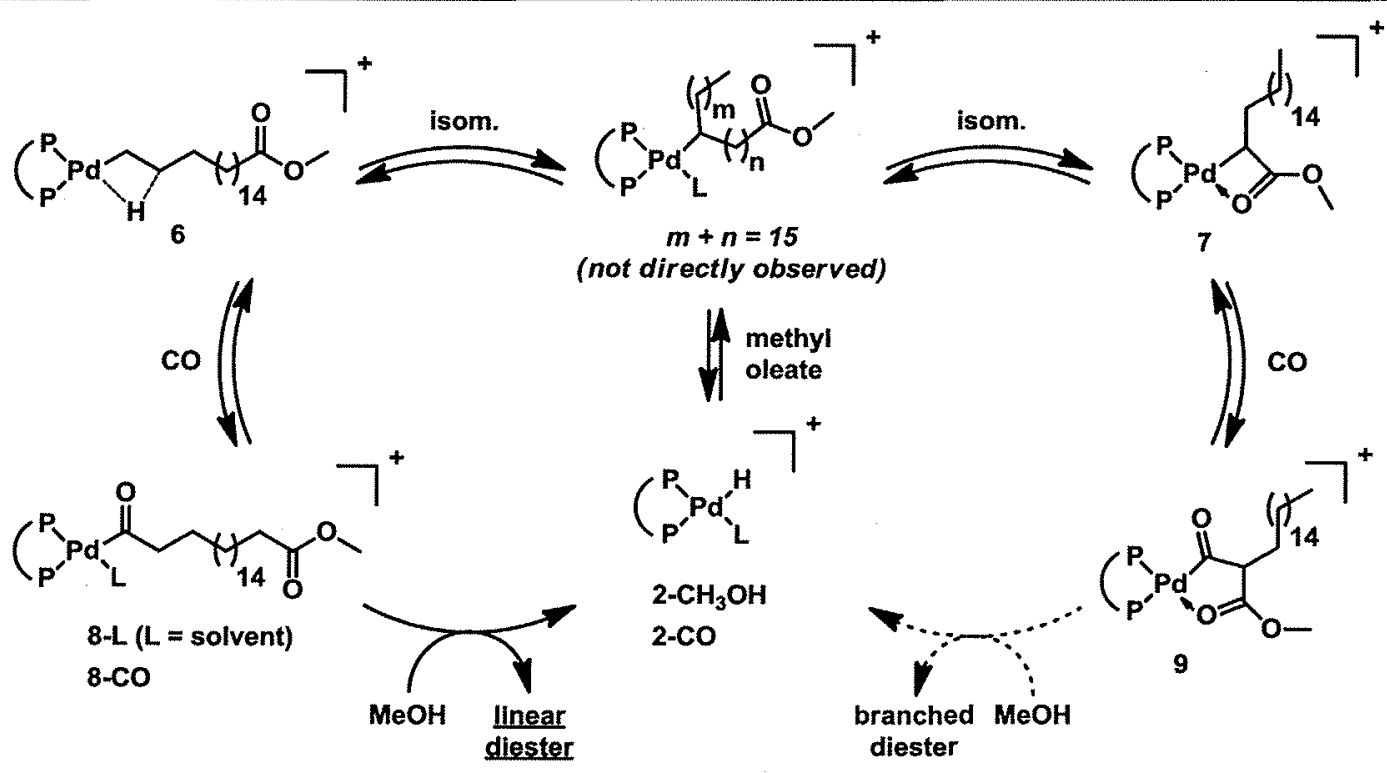

Figure 5. Decisive pathways of the isomerizing alkoxycarbonylation of methyl oleate $\left(\mathrm{P}^{\wedge} \mathrm{P}={ }^{t} \mathrm{Bu}_{2} \mathrm{P}\left(\mathrm{CH}_{2}\right)_{3} \mathrm{P}^{t} \mathrm{Bu}_{2}\right)$. 
linear alkyl (6) by far predominates over the branched midchain alkyls. Only one branched alkyl occurs in amounts roughly similar to that of the linear alkyl species, due to its stabilization by chelating coordination of the adjacent ester group from the oleate substrate (7). Both the preference of this four-membered chelate over the corresponding five- or sixmembered chelate isomers which are not observed, and the strong preference for linear alkyls over branched alkyls can be related to the extremely bulky diphosphine ligand, which restricts the available space around the other two coordination sites of the square-planar metal center.

Both the linear alkyl species and the chelate-stabilized branched alkyl species can insert $\mathrm{CO}$. The linear $\mathrm{CO}$ insertion product ( 8 ) is subject to methanolysis to the linear $\alpha, \omega$-diester product, which represents the rate-determining step of product formation. By contrast, the resulting branched acyl insertion product (9) resists methanolysis, such that the corresponding branched malonic ester does not form to any significant extent. Nonetheless, the pathway leading to 9 (right cycle in Figure 5) is not a dead end, which would shut down catalysis rapidly. While 9 possibly represents a catalyst resting state, its formation is reversible, and this dormant species can interconvert with the productive catalytic cycle (left cycle in Figure 5). These two decisive features of the reactivity of 9 are supported by theoretical studies.

In summary, the extraordinary selectivity of isomerizing alkoxycarbonylation of unsaturated fatty acid esters can be traced to two decisive points, which are responsible for the kinetically controlled formation of the linear $\alpha, \omega$-product: a preference for linear insertion products, and the relatively slow methanolysis of the branched chelating acyl. An understanding of the influence of different substituents and backbones of the diphosphines on the various underlying steps and their interplay in this synthetically very useful reaction should be an issue of interest in future studies.

\section{EXPERIMENTAL SECTION}

All manipulations of phosphines or palladium complexes were carried out under an inert nitrogen or argon atmosphere using a standard glovebox or Schlenk techniques. ${ }^{13} \mathrm{CO}$ and methyl oleate-1-1 ${ }^{13} \mathrm{C}$ were purchased from Aldrich. 1,3-Bis(di-tert-butylphosphino)propane ${ }^{26}$ and 1. ${ }^{13} \mathrm{C}$-labeled 1-octene ${ }^{27}$ were synthesized according to slightly modified literature procedures. Deuterated solvents were supplied by Eurisotop and stored over $3 \AA$ molecular sieves. NMR spectra were recorded on a Varian Unity Inova 400 equipped with a $4 \mathrm{NUC} /$ switchable mode - $5 \mathrm{~mm}$ "direct detection" probe, a Bruker Avance III 400 equipped with a BBFO plus probe or a Bruker Avance III 600 equipped with a QXI-H/C/N/P quadruple resonance probe. NMR temperature calibration was performed using pure methanol. To establish the methine proton in the $\alpha$-position of the carbonyl group a multiplicity-edited ${ }^{1} \mathrm{H},{ }^{13} \mathrm{C}$ HSQC was recorded in which the carbonyl region was decoupled using the WALTZ16 sequence (Figure S27, SI). The assignment of $\mathrm{CH}$ - and $\mathrm{CP}$-coupling patterns was supported by one-dimensional- ${ }^{13} \mathrm{C}$ spectra with additional decoupling of the ${ }^{31} \mathrm{P}$ resonances using GARP. Acquired data were processed and analyzed using MestReNova software. For detailed experimental procedures see the SI.

Synthesis of $\left[\left(P^{\wedge} \mathrm{P}\right) \mathrm{PdH}(\text { pyridine })\right]^{+}(\mathrm{OTf})^{-}(2$-pyr). Fifty milligrams of $\left[\left(\mathrm{P}^{\wedge} \mathrm{P}\right) \mathrm{Pd}(\mathrm{OTf})\right]^{+}(\mathrm{OTf})^{-}(0.068 \mathrm{mmol}, 1.0$ equiv) were dissolved in $5 \mathrm{~mL}$ of methanol (MeOH) and stirred for $15 \mathrm{~min}$ at room temperature. One milliliter of pyridine (pyr) was added, and the resulting solution was stirred for another $15 \mathrm{~min}$. Volatiles were then removed under reduced pressure, and the resulting off-white solid was washed several times with $\mathrm{Et}_{2} \mathrm{O}$. Yield: $54.9 \mathrm{mg}\left[\left(\mathrm{P}^{\wedge} \mathrm{P}\right) \mathrm{PdH}-\right.$ (pyridine) $]^{+}(\mathrm{OTf})^{-}$including $\mathrm{I}$ equiv of pyridinium triflate $(0.061$ mmol, 90\%). ${ }^{1} \mathrm{H}$ NMR (400 MHz, $25{ }^{\circ} \mathrm{C}, \mathrm{CD}_{2} \mathrm{Cl}_{2}$ ): $\delta 14.20$ (s br,
$1 \mathrm{H}), 8.79\left(\mathrm{~d},{ }^{3} J_{\mathrm{HH}}=5.6 \mathrm{~Hz}, 2 \mathrm{H}\right), 8.64\left(\mathrm{~d},{ }^{3} J_{\mathrm{HH}}=4.7 \mathrm{~Hz}, 2 \mathrm{H}\right), 8.57(\mathrm{t}$, $\left.{ }^{3} J_{\mathrm{HH}}=7.9 \mathrm{~Hz}, 1 \mathrm{H}\right), 8.04\left(\mathrm{vt},{ }^{3} J_{\mathrm{HH}}=6.6 \mathrm{~Hz}, 2 \mathrm{H}\right), 7.89\left(\mathrm{t},{ }^{3} J_{\mathrm{HH}}=7.7\right.$ $\mathrm{Hz}, 1 \mathrm{H}), 7.53\left(\mathrm{vt},{ }^{3} J_{\mathrm{HH}}=6.4 \mathrm{~Hz}, 2 \mathrm{H}\right), 2.10(\mathrm{~m}, 2 \mathrm{H}), 1.75(\mathrm{~m}, 2 \mathrm{H})$, $1.66(\mathrm{~m}, 2 \mathrm{H}), 1.22\left(\mathrm{~d},{ }^{3} J_{\mathrm{PH}}=14.8 \mathrm{~Hz}, 18 \mathrm{H}\right), 1.12\left(\mathrm{~d},{ }^{3} J_{\mathrm{PH}}=12.9 \mathrm{~Hz}\right.$, $18 \mathrm{H}),-9.07\left(\mathrm{dd},{ }^{2} J_{\mathrm{PH}_{\text {taxs }}}=190.6,{ }^{2} J_{\mathrm{PH}_{\mathrm{cis}}}=17.7 \mathrm{~Hz}, 1 \mathrm{H}\right) \cdot{ }^{13} \mathrm{C}\left\{{ }^{1} \mathrm{H}\right\} \mathrm{NMR}$ $\left(100 \mathrm{MHz}, 25^{\circ} \mathrm{C}, \mathrm{CD}_{2} \mathrm{Cl}_{2}\right): \delta 152.09(\mathrm{~s}), 146.78(\mathrm{~s} \mathrm{br}), 141.60(\mathrm{~s} \mathrm{br})$, $138.85(\mathrm{~s}), 127.55(\mathrm{~s} \mathrm{br}), 125.76(\mathrm{~s}), 120.28\left(\mathrm{q},{ }^{1} J_{\mathrm{CF}}=320.1 \mathrm{~Hz}\right.$, $\left.\mathrm{O}_{3} \mathrm{SCF}_{3}\right), 35.84\left(\mathrm{~d},{ }^{1} J_{\mathrm{Cp}}=28.9 \mathrm{~Hz}\right), 35.32\left(\mathrm{~d},{ }^{1} J_{\mathrm{Cp}}=11.1 \mathrm{~Hz}\right), 29.52$ $\left(\mathrm{d},{ }^{2} J_{\mathrm{CP}}=5.3 \mathrm{~Hz}\right), 29.21\left(\mathrm{~d},{ }^{2} J_{\mathrm{CP}}=2.9 \mathrm{~Hz}\right), 22.61\left(\mathrm{~d},{ }^{2} J_{\mathrm{CP}}=5.0 \mathrm{~Hz}\right)$, $19.00\left(\mathrm{dd},{ }^{1} J_{\mathrm{CP}}=14.8 \mathrm{~Hz},{ }^{3} J_{\mathrm{CP}}=3.2 \mathrm{~Hz}\right), 18.21\left(\mathrm{dd},{ }^{1} J_{\mathrm{CP}}=17.2,{ }^{3} J_{\mathrm{CP}}=\right.$ $7.8 \mathrm{~Hz}) .{ }^{3 \mathrm{l}} \mathrm{P}\left({ }^{\mathrm{l}} \mathrm{H}\right\} \mathrm{NMR}\left(162 \mathrm{MHz}, 25^{\circ} \mathrm{C}, \mathrm{CD}_{2} \mathrm{Cl}_{2}\right): \delta 65.32\left(\mathrm{~d},{ }^{2} \mathrm{Jpp}_{\mathrm{p}}=\right.$ $26.0 \mathrm{~Hz}), 19.68\left(\mathrm{~d},{ }^{2} \mathrm{JPp}_{\mathrm{Pp}}=26.0 \mathrm{~Hz}\right) \cdot{ }^{19} \mathrm{~F}\left\{{ }^{1} \mathrm{H}\right\}$ NMR $\left(376 \mathrm{MHz}, 25^{\circ} \mathrm{C}\right.$ $\left.\mathrm{CD}_{2} \mathrm{Cl}_{2}\right) ; \delta-79.67(\mathrm{~s})$. Elemental Analysis: calculated: $\mathrm{C} \mathrm{41.50 \% , \textrm {H }}$ $6.07 \%$, N $3.12 \%$; found: C $41.06 \%$, H $6.16 \%$, N $3.13 \%$.

NMR Tube Experiments. NMR tubes were charged with solid reagents and the appropriate solvent or solvent mixture in a glovebox. All tubes were sealed with rubber septa. Liquid reactants were added with Hamilton microliter syringes, and tubes were thoroughly shaken after each addition. To adjust low temperatures, isopropanol/dry-ice cooling baths were used, and temperatures were checked prior to each step. Unless noted otherwise, carbon monoxide was added at low temperatures using a three-way stopcock, a compressed gas cylinder equipped with a pressure relief valve that was connected to a vacuum line, and a small Schlenk flask sealed with a rubber septum. The system was evacuated and backfilled with 1 atm (ambient pressure) of CO. Gas was transferred into the NMR tubes with $1 \mathrm{~mL}$ syringes, and tubes were briefly shaken after each addition. For calculating the appropriate volume, ideal gas conditions were assumed.

Computational Details. DFT calculations were performed with the Gaussian09 package $^{28}$ using the $B 3 L Y P^{29}$ functional and the LANL2DZ ECP ${ }^{30}$ with the associated valence basis set on the Pd atom and the $6-31 \mathrm{G}(\mathrm{d})^{31}$ basis set on all the other atoms. All geometries were localized in the gas phase at the B3LYP level. Minima were localized by full optimization of the starting structures, while transition states for $\mathrm{CO}$ insertion and for the methanolysis reaction were approached through a linear transit procedure starting from the $\mathrm{CO}$ and the methanol (as a single molecule and as a three-molecule cluster) coordination intermediate and then located by a full transition state search. All structures were confirmed as minimum or transition state through frequency calculations.

In all the calculations we used the $1,2-\left(\mathrm{CH}_{2} \mathrm{P}^{t} \mathrm{Bu}_{2}\right)_{2} \mathrm{C}_{6} \mathrm{H}_{4}$ ligand because it has a somewhat more rigid phosphine backbone compared to the 1,3-bis(di-tert-butylphosphino)propane ligand. This rigidity reduces the number of conformers and facilitates the identification of ground and transition states. This decision was based on the experimental observation that the two $\mathrm{Pd}(\mathrm{II})$ complexes show a similar performance in the methoxycarbonylation of methyl oleate. Finally, the linear alkyl $\left[\left(\mathrm{P}^{\wedge} \mathrm{P}\right) \mathrm{PdCH}_{2}\left(\mathrm{CH}_{2}\right)_{5} \mathrm{COOCH}_{3}\right]^{+}$and the branched alkyl $\left[\left(\mathrm{P}^{\wedge} \mathrm{P}\right) \mathrm{PdCH}\left\{\left(\mathrm{CH}_{2}\right)_{4} \mathrm{CH}_{3}\right\} \mathrm{COOCH}_{3}\right]^{+}$species were selected as smaller suitable systems to model the Pd-alkyl complexes 6 and 7 respectively (Figure $\mathrm{S} 43, \mathrm{SI}$ ).

\section{AUTHOR INFORMATION}

\section{Corresponding Author}

stefan.mecking@uni-konstanz.de; lcaporaso@unisa.it; heiko. moeller@uni-konstanz.de

\section{Notes}

The authors declare no competing financial interest. 


\section{ACKNOWLEDGMENTS}

P.R. gratefully acknowledges support from the Carl-ZeissFoundation by a graduate fellowship. S.M. is indebted to the Fonds der Chemischen Industrie.

\section{REFERENCES}

(1) (a) Biermann, U.; Bornscheuer, U.; Meier, M. A. R.; Metzger, J. O.; Schäfer, H. J. Angew. Chem., Int. Ed. 2011, 50, 3854-3871. (b) Chikkali, S.; Mecking, S. Angew. Chem., Int. Ed. 2012, 51, 58025808

(2) Picataggio, S.; Rohrer, T,; Deanda, K; Lanning, D.; Reynolds, R; Mielenz, J.; Eirich, L. D. Nat. Biotechnol. 1992, 10, 894-898. (b) Schoerken, U.; Kempers, P. Eur. J. Lipid Sci. Technol. 2009, 111, $627-645$

(3) Lu, W.; Ness, J. E.; Xie, W.; Zhang, X.; Minshull, J.; Gross, R A. J. Am. Chem. Soc. 2010, 132, 15451-15455.

(4) (a) van der Veen, L. A.; Kamer, P. C. J.; van Leeuwen, P. W. N. M. Angew. Chem, Int. Ed. 1999, 38, 336-338. (b) Selent, D.; Hess, D.; Wiese, K D.; Röttger, D.; Kunze, C.; Börner, A. Angew. Chem., Int. Ed. 2001, 40, 1696-1698. (c) Behr, A.; Obst, D.; Westfechtel, A. Eur. J. Lipid Sci. Technol. 2005, 107, 213-219.

(5) (a) Colquhoun, H. M.; Thompson, D. J.; Twigg, M. V. Carbonylation, Plenum, New York, 1991. (b) Beller, M.; Tafesh, A. M. In Applied Homogeneous Catalysis with Organometallic Compounds; Cornils, B., Herrmann, W. A., Eds.; Wiley-VCH: Weinheim, 2000; pp 178-201. (c) van Leeuwen, P. W. N. M.; Claver, C. In Comprehensive Coordination Chemistry II; McCleverty, J. A., Meyer, T. J., Eds.; Elsevier: Oxford, 2004; Vol. 9, pp 141-206.

(6) (a) Clegg, W.; Eastham, G. R.; Elsegood, M. R. J.; Tooze, R. P.; Wang, X. L.; Whiston, K. Chem. Commun. 1999, 1877-1878. (b) Clegg, W.; Eastham, G. R.; Elsegood, M. R. J.; Heaton, B. T.; Iggo, J. A.; Tooze, R. P.; Whyman, R; Zacchini, S. Organometallics 2002, 21, 1832-1840. (c) Liu, J.; Heaton, B. R.; Iggo, J. A.; Whyman, R; Bickley, J. F.; Steiner, A. Chem.-Eur. J. 2006, 12, 4417-4430. (d) van Leeuwen, P. W. N. M.; Zuideveld, M. A.; Swennenhuis, B. H. G.; Freixa, Z.; Kamer, P. C. J.; Goubitz, K. Fraanje, J.; Lutz, M.; Spek, A. L. J. Am. Chem. Soc, 2003, 125, 5523-5539. (e) Donald, S. M. A.; Macgregor, S. A.; Settels, V.; Cole-Hamilton, D. J.; Eastham, G. R. Chem. Commun. 2007, 562-564. (f) de la Fuente, V.; Waugh, M.; Eastham, G. R; Iggo, J. A.; Castillon, S.; Claver, C. Chem.-Eur. J. 2010, 16, 6919-6932.

(7) (a) McCoy, M.; Tremblay, J.-F. Chem. Eng. News 2009, 87 (33), 9. (b) Harris, B. Ingenia 2010, No. issue 45, 19-23.

(8) (a) Eastham, G. R; Heaton, B. T.; Iggo, J. A.; Tooze, R. P.; Whyman, R.; Zacchini, S. Chem. Commun. 2000, 609-610. (b) Frew, J. J. R; Damian, K.; Van Rensburg, H.; Slawin, A. M. Z.; Tooze, R. P; Clarke, M. L. Chem.-Eur. J. 2009, 1S, 10504-10513. (c) Clegg, W.; Eastham, G. R.; Elsegood, M. R. J.j Heaton, B. T.j Iggo, J. A.; Tooze, R. P.; Whyman, R, Zacchini, S. J. Chem. Soc, Dalton Trans. 2002, 17, 3300-3308. (d) van Leeuwen, P. W. N. M.; Zuideveld, M. A.; Swennenhuis, B. H. G.; Freixa, Z.; Kamer, P. C. J.; Goubitz, K; Fraanje, J.; Lutz, M.; Spek, A. L. J. Am. Chem. Soc. 2003, 125, 55235539.

(9) (a) Pugh, R I.; Drent, E.; Pringle, P. G. Chem. Commun. 2001, 1476-1477. (b) Jiménez-Rodriguez, C.; Foster, D. F.; Eastham, G. R; Cole-Hamilton, D. J. Chem. Commun. 2004, 1720-1721.

(10) (a) Jiménez-Rodriguez, C.; Eastham, G. R. Cole-Hamilton, D. J. Inorg. Chem. Commun. 200S, 8, 878-881. (b) Furst, M. R. L.; Le Goff, R.; Quinzler, D.; Mecking, S.; Botting, C. H.; Cole-Hamilton, D. J. Green Chem. 2012, 14, 472-477. (c) Walther, G.; Deutsch, J.; Martin, A.; Baumann, F.-E.; Fridag, D.; Franke, R.; Kockritz, A. Chem SusChem 2011, 4, 1052-1054.

(11) Quinzler, D.; Mecking, S. Angew. Chem., Int. Ed. 2010, 49, $4306-4308$.

(12) Stempfle, F.; Quinzler, D.; Heckler, 1.; Mecking, S. Macromolecules 2011, 44, 4159-4166.

(13) (a) Portnoy, M.; Milstein, D. Organametallics 1994, 13, 600609. (b) Portnoy, M.; Frolow, F.; Milstein, D. Organometallics 1991,
10, 3960-3962. (c) Tóth, l.; Elsevier, C. J. Organometallics 1994, 13, 2118-2122. (d) Minghetti, G.; Bandini, A. L.; Banditelli, G.; Bonati F.j Szostak, R; Strouse, C. E.; Knobler, C. B.; Kaesz, H. D. Inorg Chem. 1983, 22, 2332-2338. (e) Perez, P. J.; Calabrese, J. C.; Bunel, E. E. Organometallics 2001, 20, 337-345

(14) Baya, M.; Houghton, J.; Konya, D.; Champouret, Y.; Daran, J. C.; Leñero, K. Q. A.; Schoon, L.; Mul, W. P.; van Oort, A. B. Meijboom, N.; Drent, E.; Orpen, A. G.; Poli, R. J. Am. Chem. Soc. 2008, 130, 10612-10624.

(15) (a) Dayma, G.; Gail, S.; Dagaut, P. Energy Fuels 2008, 22, 1469-

1479. (b) Vatani, A.; Mehrpooya; Gharagheizi, F. Int. J. Mol. Sci. 2007 $8,407-432$.

(16) Key resonances $\left(-80^{\circ} \mathrm{C}\right)$ of this reactive species are: $\delta^{\mathrm{t}} \mathrm{H}$ -9.80 (doublet of doublet with ${ }^{2} J_{\mathrm{PH}}=193.0 \mathrm{~Hz}$ and ${ }^{2} J_{\mathrm{PH}}=25.7$ $\mathrm{Hz}$ ) for $\mathrm{Pd}-\mathrm{H}$ and $\delta^{31} \mathrm{P} 72.81$ and 20.96 (doublet each, ${ }^{2} J_{\mathrm{PP}}=23.6$ $\mathrm{Hz}$ ).

(17) For a similar complex $\left[\left(\mathrm{P}^{\wedge} \mathrm{P}\right) \mathrm{PdCH}_{2} \mathrm{CH}_{3}\right]^{+}$, with $\mathrm{P}^{\wedge} \mathrm{P}=1,2$ bis((di-tert-butylphosphino)methyl)benzene, $\delta{ }^{13} \mathrm{C} 32.0$ with ${ }^{2} \mathrm{P}_{\mathrm{PC}_{\text {lus }}}=$ $38.0 \mathrm{~Hz}$ and $\delta^{31} \mathrm{p} 67.7$ and 36.3 (doublet each, ${ }^{2} J_{\mathrm{IP}}=31.0 \mathrm{~Hz}$ ) was found at $-80{ }^{\circ} \mathrm{C}$ in methanol (see ref $6 \mathrm{~b}$ ).

(18) Addition of 5.5 equiv of 1-octene to a solution of $2-\mathrm{CH}_{3} \mathrm{OH}$ in $\mathrm{CD}_{2} \mathrm{Cl}_{2} / \mathrm{MeOH}(\mathrm{v} / \mathrm{v}=3 / 2)$ at $-80^{\circ} \mathrm{C}$ shifts the equilibrium between free olefin plus hydride and its insertion product completely towards the olefin insertion product. $\delta^{31} \mathrm{P} 62.23$ and 38.99 (doublet each, ${ }^{2} J_{\mathrm{Pl}}$ $=36.0 \mathrm{~Hz}$ ).

(19) Key resonances of 5-L are as follows: $\delta^{31} \mathrm{P} 76.42$ and 34.78 (multiplet each) for the two inequivalent phosphorus atoms and $\delta{ }^{13} \mathrm{C}$ 235.11 (multiplet, carbonyl group), 44.66 (multiplet, $\alpha$-methylene group) and 14.17 (singlet, terminal methyl group); key resonances of 5- ${ }^{13} \mathrm{CO}$ are: $\delta{ }^{31} \mathrm{P} 31.49$ and 28.12 (multiplet each) for the two inequivalent phosphorus atoms and $\delta^{13} \mathrm{C} 232.12$ (multiplet, carbonyl group), 177.82 (multiplet, coordinated ${ }^{13} \mathrm{CO}$ ), 62.34 (multiplet, $\alpha$ methylene group) and 14.17 (singlet, terminal methyl group); multiplet coupling patterns are elucidated in the SI (Figures S18 and S19).

(20) Key resonances of 8-L are: $\delta^{31} \mathrm{P} 76.52$ (doublet of doublet with ${ }^{2} J_{\mathrm{pp}}=44.5 \mathrm{~Hz}$ and ${ }^{2} J_{\mathrm{PC}}=16.3 \mathrm{~Hz}$ ) and 34.86 (doublet of doublet with ${ }^{2} J_{\mathrm{pp}}=44.5 \mathrm{~Hz}$ and ${ }^{2} \mathrm{~J}_{\mathrm{PC}}=81.7 \mathrm{~Hz}$ ) for the two inequivalent phosphorus atoms. $\delta^{13} \mathrm{C} 238.74$ (multiplet, carbonyl group next to the Pd center), 174.93 (singlet, carbonyl group at chain end) and 51.69 (doublet, methoxy group). Multiplet coupling patterns are elucidated in the SI (Figure S28).

(21) Key resonances of $8{ }^{13} \mathrm{CO}$ are: $\delta^{31} \mathrm{P} 31.50$ (doublet of doublet with ${ }^{2} J_{\mathrm{pp}}=60.5 \mathrm{~Hz}$ and ${ }^{2} J_{\mathrm{PC}_{\text {trans }}}=76.8 \mathrm{~Hz}$ ) and 28.20 (doublet of doublet of doublet with ${ }^{2} J_{\mathrm{PP}}=60.5 \mathrm{~Hz}$ and ${ }^{2} J_{\mathrm{PC}_{t r+15}}=76.0 \mathrm{~Hz}$ and ${ }^{2} J_{\mathrm{PC}}$ $=23.2 \mathrm{~Hz}$ ) for the two inequivalent phosphorus atoms. $\delta^{13} \mathrm{C} 232.11$ (multiplet, carbonyl group next to the Pd center), 177.82 (multiplet, coordinated $\left.{ }^{13} \mathrm{CO}\right), 174.93$ (singlet, carbonyl group at chain end) and 51.69 (doublet, methoxy group). Multiplet coupling patterns are elucidated in the SI (Figure S29)

(22) Key resonances of 9 are: 58.31 (doublet of doublet with ${ }^{2} J_{p p}=$ $49.6 \mathrm{~Hz}$ and ${ }^{2} J_{\mathrm{PC}}=15.8 \mathrm{~Hz}$ ) and 24.06 (doublet of doublet with ${ }^{2} J_{\mathrm{Pp}}$ $=49.6 \mathrm{~Hz}$ and ${ }^{2} J_{\mathrm{PC}_{\text {tras }}}=114.9 \mathrm{~Hz}$ ) for the two inequivalent phosphorus atoms. $\delta{ }^{13} \mathrm{C} 222.61$ (multiplet, carbonyl group next to the Pd center), 182.49 (doublet, carbonyl group coordinated to the Pd center), 72.48 (broad multiplet, methine group) and 57.08 (doublet, methoxy group). Multiplet coupling patterns are elucidated in the SI (Figure S30).

(23) Likewise, addition of 0.5 equiv of methanol to $5-\mathbf{L}$ and $5-{ }^{13} \mathrm{CO}$ (prepared by addition of 1.5 equiv of ${ }^{13} \mathrm{CO}$ to 4 ) at $-80^{\circ} \mathrm{C}$ resulted in fast methanolysis as evidenced by a rapid decrease of the ${ }^{31} \mathrm{P}$ NMR resonances of $5-\mathrm{L}$. Immediate formation of linear methyl nonanoate and complete consumption of methanol was observed (Figure S21 SI).

(24) Note that there is still a small amount of $2^{\mathrm{D}}-\mathrm{CD}_{3} \mathrm{OD}$ present, as the equilibrium between free olefin plus hydride $\left(2^{\mathrm{D}} \cdot \mathrm{CD}_{3} \mathrm{OD}\right)$ and its 
insertion products ( 6 and 7) is not completely shifted towards the olefin insertion product.

(25) Likewise, addition of carbon monoxide to a solution of 4 (prepared by addition of 1 -octene to $2^{\mathrm{D}}-\mathrm{CD}_{3} \mathrm{OD}$ ) in a $\mathrm{CD}_{3} \mathrm{OD} /$ $\mathrm{CD}_{2} \mathrm{Cl}_{2}$ mixture $\left(2 / 3\right.$ by volume) at $-80^{\circ} \mathrm{C}$ resulted in formation of linear methyl nonanoate.

(26) Carr, N.; Dunne, B. J.; Mole, L.; Orpen, A. G.; Spencer, J. L. J. Chem. Soc, Dalton Trans. 1991, 863-871.

(27) (a) Liu, Z.; Somsook, E.; White, C. B.; Rosaaen, K. A.; Landis, C. R. J. Am. Chem. Soc. 2001, 123, 11193-11207. (b) Babushkin, D. E; Brintzinger, H. H. J. Am. Chem. Soc. 2009, 132, 452-453.

(28) Frisch, J.; Trucks, G. W.; Schlegel, H. B.; Scuseria, G. E.; Robb, M. A.; Cheeseman, J. R.; Montgomery Jr., J. A.; Vreven, T.; Kudin, K, N.; Burant, J. C.; Millam, J. M.; Iyengar, S. S.; Tomasi, J.; Barone, V.; Mennucci, B.; Cossi, M.; Scalmani, G.; Rega, N.; Petersson, G. A.; Nakatsuji, H.; Hada, M.; Ehara, M.; Toyota, K.; Fukuda, R; Hasegawa, J.; Ishida, M.; Nakajima, T.; Honda, Y.; Kitao, O.; Nakai, H.; Klene, M.; Li, X.; Knox, J. E.; Hratchian, H. P.; Cross, J. B.; Bakken, V.; Adamo, C.; Jaramillo, J.; Gomperts, R; Stratmann, R. E; Yazyev, O.; Austin, A. J.; Cammi, R,; Pomelli, C.; Ochterski, J. W.; Ayala, P. Y.; Morokuma, K.; Voth, G. A.; Salvador, P.; Dannenberg, J. J.; Zakrzewski, V. G.; Dapprich, S.; Daniels, A. D.; Strain, M. C.; Farkas, O.; Malick, D. K.; Rabuck, A. D.; Raghavachari, K.; Foresman, J. B.; Ortiz, J. V.; Cui, Q.; Baboul, A. G.; Clifford, S.; Cioslowski, J.; Stefanov, B. B.; Liu, G.; Liashenko, A.; Piskorz, P.; Komaromi, I.; Martin, R. L.; Fox, D. J.; Keith, T.; Al-Laham, M. A.; Peng, C. Y.; Nanayakkara, A; Challacombe, M.; Gill, P. M. W.; Johnson, B.; Chen, W.; Wong, M. W.; Gonzalez, C.; Pople, J. A. Gaussian03, Revision C.02; Gaussian, Inc.: Wallingford CT, 2004.

(29) Becke, A. D. J. Chem. Phys. 1993, 98, 5648-5652.

(30) (a) Dunning Jr., T. H.; Hay, P. J. In Modern Theoretical Chemistry; Schaefer III, H. F., Ed.; Plenum: New York, 1976; pp 1-28. (b) Hay, P. J.; Wadt, W. R. J. Chem. Phys. 1985, 82, 270-283.

(3I) (a) Ditchfield, R.; Hehre, W. J; Pople, J. A. J. Chem. Phys. 1971, 54, 724-728. (b) Hehre, W. J.; Ditchfield, R; Pople, J. A. J. Chem. Phys. 1972, 56, 2257-2261. (c) Hariharan, P. C.; Pople, J. A. Mol. Phys. 1974, 27, 209-214. (d) Gordon, M. S. Chem. Phys. Lett. 1980, 76, 163-168. (e) Hariharan, P. C.; Pople, J. A. Theor. Chim. Acta $1973,28,213-222$. 